\title{
Antiangiogenic Gene Therapy in Cancer
}

\author{
L. Zhang, Q.R. Chen, and A. J. Mixson ${ }^{1}$ \\ Department of Pathology, University of Maryland at Baltimore, MD 21201
}

\begin{abstract}
One of the most recent and exciting approaches in cancer gene therapy is the ability to target the developing blood supply of the tumor. An appealing feature of antiangiogenic gene therapy is that the tumor vasculature is a readily accessible target, particularly when the carrier and its gene are administered systemically. This is in contrast to several other gene therapy approaches in which the tumor vasculature represents a major obstacle to achieving high levels of transfection of the tumor cells. Several gene-based viral or non-viral therapies that target tumor angiogenesis have shown efficacy in pre-clinical models. Genes that encode antiangiogenic polypeptides such as angiostatin and endostatin have significantly inhibited tumor growth, inducing a microscopic dormant state. The products of these genes are thought to act extracellularly to inhibit angiogenesis. An alternative approach that investigators have used successfully in tumor-bearing mice is to target angiogenic growth factors or their receptors that are essential for tumor growth. Levels of angiogenic factors such as vascular endothelial growth factor (VEGF) have been reduced by either antisense methods or the use of genes encoding truncated angiogenic decoy receptors. Despite these promising findings of tumor reduction with antiangiogenic gene therapy, advances in the viral and/or non-viral delivery systems are essential for this therapy to have clinical utility. In this review, we will discuss the mechanisms of angiogenesis/antiangiogenesis, and the current status and future directions of antiangiogenic gene therapy.
\end{abstract}

\section{Introduction}

One of the key advances in our understanding of tumor biology is the realization that tumor growth is dependent on angiogenesis, the formation of new blood vessels (1). This fundamental principle states that tumor progression beyond $2 \mathrm{~mm}$ in diameter requires angiogenesis (2). Activation of growth factors that stimulate angiogenesis together with suppression of angiogenic inhibitors are frequent hallmarks of tumor growth (Table I). Therefore, antiangiogenic gene therapy attempts to reduce tumor growth either by reducing angiogenic growth factors or by increasing angiogenic inhibitors within a tumor (3).

In contrast to the situation with many gene therapy methods, the vasculature is not a significant obstacle to the antiangiogenic gene therapy approach. Since the tumor vasculature is readily accessible to systemic therapy, targeting mitogenic endothelial cells of the tumor increases the likelihood that gene therapy with antiangiogenic genes will be successful. Antiangiogenic gene therapy may also circumvent the problem of acquired

\footnotetext{
${ }^{1}$ To whom request for reprints should be addressed at, Department of Pathology, University of Maryland at Baltimore, Rm. 7-59, Bldg. MSTF., 10 S. Pine Street, Baltimore, MD 21201. Tel: 410-706-3223; Fax: 410-706-8414.
} 
anticancer drug resistance. If endothelial cells are targeted by this therapy, the relative genomic stability of the endothelial cells within tumors may reduce the emergence of drug resistance $(4,5)$. Another potential advantage of antiangiogenic gene therapy is the significant homology of the angiogenic/antiangiogenic proteins and their receptors found in animal models and man. As a result, animal models may have more utility in predicting tumor responses of antiangiogenic genes in man than other gene therapy approaches.

There are now several reports demonstrating the utility of antiangiogenic gene therapy in tumor-bearing mouse models. Investigators, first using ex vivo and later in vivo models, have successfully inhibited tumor growth by gene therapy approaches that inhibit angiogenic glycoproteins (VEGF, angiopoietin 2) and/or their receptors (6-9). More recently, gene therapy experiments with angiostatin and endostatin have also shown marked antitumor efficacy (10-12). With these successful experiments, there has been increased interest in antiangiogenic gene therapy. Whereas gene therapy with antiangiogenic genes was unrealistic a few years ago, there are now several gene therapy studies demonstrating its antitumor efficacy in pre-clinical models.

\section{Molecular pathways controlling angiogenesis/ antiangiogenesis}

Angiogenesis is a normal part of physiologic processes that occur in wound healing and in the formation of the corpus luteum. Many of the factors that play a role in physiologic angiogenesis are also important components in tumor angiogenesis. Increases in proangiogenic factors with concomitant reduction of angiogenic inhibitors are essential for tumors to grow (Fig. 1). In this section, we will first discuss the physiological role of the angiogenic or antiangiogenic factor and then consider its role in neoplastic processes. We have limited the scope of this review primarily to factors that have been targeted with gene therapy.

\section{A. VEGF and Receptors}

VEGF, a disulfide-linked 46-kDa dimeric glycoprotein, is a specific mitogen for endothelial cells $(13,14)$. VEGF, formerly known as vascular permeability factor (VPF), can also produce vascular hyperpermeability which is believed to be important in angiogenesis (15, 16). Hypoxia has been shown to increase the expression of VEGF in many cell types (15). One mediator of hypoxia-induced VEGF expression is adenosine, which binds to the adenosine subtype $2 \mathrm{~B}$ receptor $(17,18)$. Furthermore, a number of cytokines such as transforming growth factor $\beta$ (TGF $\beta$ ) and tumor necrosis factor a (TNF-a) can stimulate the production of VEGF. By promoting angiogenesis, deregulated VEGF expression contributes to the development of diseases such as psoriasis, diabetic retinopathy, and cancer. Five alternatively spliced VEGF mRNAs, encoding the isoforms of 121, 145, 165, 189, and 206 amino acids, have now been characterized. The predominant isoforms of VEGF, 121 and 165, are expressed in many different tissues.

Adding to the complexity of the alternatively spliced VEGF glycoproteins are the two VEGF receptors, VEGFR1 (also named flt-1) and VEGFR2 (also named $f 1 k-1$ or KDR). Both VEGFR1 and VEGFR2 are tyrosine kinase receptors with seven extracellular immunoglobulin-like domains. These receptors are specifically localized to mitogenic 
endothelial cells. Whereas the VEGFR1 receptor appears to be important for migration of endothelial cells, the VEGFR2 receptor is essential for mitogenesis. Upon binding to VEGF, these receptors dimerize and subsequently may induce divergent signal transduction pathways (14). An extracellular soluble form of VEGFR1 that may modulate the activity of VEGF has also been identified $(19,20)$.

In addition to these high-affinity VEGF receptors, there are co-receptors that can alter the affinities of certain VEGF isoforms for their receptors. These membrane- bound receptors include heparin-sulfate proteoglycans, and neurophilins 1 and $2(14,21)$. Although the presence of these co-receptors on endothelial cells enhances the binding and bioactivity of VEGF to high-affinity VEGF receptors, the co-receptors by themselves do not activate signal transduction pathways (21).

In tumors, VEGF appears to be the most important and specific angiogenic factor in stimulating blood vessel development (22). Indeed, elevated VEGF levels are found in the vast majority of tumors. Increased serum levels of VEGF are found in cancer patients and correlate with a poor prognosis in several different types of cancers (breast, ovarian, lung, gastric, and colon). Furthermore, blocking antibodies to VEGF have been shown to inhibit tumor development in mice (23).

A number of early studies established that when a tumor reaches $2 \mathrm{~mm}$ or greater in diameter, angiogenesis is required for further tumor growth $(2,24,25)$. These experiments suggest that VEGF plays a significant role in early tumor growth (Fig. 2). However, VEGF and its interaction with other angiogenic components in the tumor such as angiopoietin may be more complex than previously understood (see section on angiopoietin).

Although VEGF levels and angiogenesis are markedly increased at early stages of tumor growth when tumor cells are transplanted into tissues with low vascularity (e.g., subcutaneous), one recent study demonstrated that VEGF levels remained low even when metastases to vascular organs (e.g. brain or lung) were greater than or equal to $2 \mathrm{~mm}$ in diameter (26). At these early stages, the growing tumor, instead of promoting angiogenesis, co-opted the vessels of the normal tissue to obtain essential nutrients (Fig. 2). When the tumor grew to several millimeters in size, however, VEGF levels were up-regulated and became essential for angiogenesis and further tumor growth.

\section{B. Angiopoietins 1,2 and the Tie Receptors}

Angiopoietin 1 and 2 are highly homologous cytokines that bind with similar affinities to the endothelium-specific receptor, Tie2. Nevertheless, the physiological consequences of binding by these ligands are different. Angiopoietin 1, which appears to have a significant role in stabilizing vessels, activates the tyrosine kinase Tie2 receptor and the subsequent signal transduction pathway (Fig. 3). Despite the high homology with angiopoietin 1, angiopoietin 2 binds to but does not activate the Tie 2 receptor. During development, angiopoietin 2 causes apoptosis of the vessel in the absence in VEGF. In the presence of VEGF, however, angiopoietin 2 stimulates angiogenesis perhaps by disrupting the integrity of the vessels (Fig. 3). This interplay between VEGF and the angiopoietins has an important 
role in the corpus luteum. Although Tie 1 and 2 are highly homologous tyrosine kinase receptors, a ligand has not been identified for the Tie 1 receptor (27).

Similar to the interplay that occurs in the corpus luteum, it appears that angiopoietins cooperate with VEGF to remodel tumor vasculature. Investigators recently found that newly formed tumor metastases in vascular tissues do not obtain most of their nutrient and oxygen from angiogenic vessels but rely on existing vessels in the target organs (26). As stated previously, the developing tumors co-opt these existing host vessels. These co-opted vessels do not immediately undergo angiogenesis but instead regress, leading to massive tumor cell loss. The remaining tumor is then rescued by a classical angiogenesis response. The expression patterns of VEGF and angiopoietin 2 correspond to the changes seen in the tumor. Early in tumor development, the levels of VEGF are low, whereas angiopoietin 2 is up-regulated and diffusely scattered throughout the tumor. Thus, in the absence of VEGF, angiopoietin 2 may mark the endothelial cells for destruction. At a later stage when the tumor is large with central necrosis, both angiopoietin 2 and VEGF are up-regulated primarily in the peripheral zones of the tumor (Fig. 2B), and there is marked angiogenesis and tumor growth in these zones. Thus, the presence of VEGF determines whether angiopoietin 2 induces apoptosis of endothelial cells or stimulates angiogenesis and tumor growth.

\section{Fibroblast Growth Factors}

In contrast to VEGF and the angiopoietins which specifically affect the endothelium, fibroblast growth factor 1 (FGF1, acidic) and fibroblast growth factor 2 (FGF2, basic) exhibit a variety of biological functions in many tissues and organs (22). FGF1 and FGF2 stimulate the proliferation of several cells including fibroblasts, endothelial cells, astrocytes, oligodendrocytes, neuroblasts, keratinocytes, osteoblasts, and smooth muscle cells. In addition, FGF2 is chemotactic for endothelial cells. Whereas VEGF induces the $\alpha_{v} \beta_{5}$ integrin pathway, FGF2 stimulates angiogenesis through the $\alpha_{\mathrm{v}} \beta_{3}$ integrin pathway (28). FGF1 and FGF2 bind to one of four high affinity tyrosine kinase receptors. In addition, cell surface low affinity glycosaminoglycan co-receptors have been found to enhance FGF binding to the high affinity receptors.

Whether FGF2 has a direct role in tumor angiogenesis is inconclusive. Many investigators have extrapolated from in vitro and in vivo angiogenic assays utilizing FGF2 to explain the promotion of tumor growth in vivo. However, there is little evidence to show that fibroblast growth factor receptors (FGFR) are present in the microvessels of a tumor (29). The lack of measurable FGFR on the tumor endothelium is in marked contrast to the expression of the VEGF receptors. It has been suggested that FGF2 in vivo may increase angiogenesis by inducing other angiogenic growth factors such as VEGF (30). Although its role in angiogenesis in vivo is uncertain, there is evidence to suggest that FGF2 has a role in promoting tumor growth. Neutralizing antibodies to FGF2 have been shown to prevent development of tumors in pre-clinical models (31). Furthermore, elevated FGF2 levels, which have been detected in several types of malignancies, are associated with a poor prognosis $(32,33)$. 


\section{P53 and thrombospondin}

Although the vast majority of studies with p53 have emphasized its ability to inhibit the cell cycle, p53 is able to stimulate several antiangiogenic mechanisms (discussed in more detail below). It was reported initially that inactivation of p53 did not affect embryological development, as studies on knockout mice primarily focused on the rapid development of tumors in these mice. Nevertheless, there appear to be subtle effects on embryological development regulated by p53 (34). It has been suggested that p53 plays a role during development in neuronal apoptosis and in controlling mutagenesis (35). At present, there is no direct evidence that $\mathrm{p} 53$ has a role in vasculogenesis during embryogenesis or in normal physiologic processes related to angiogenesis

In vitro experiments have shown that p53 may affect angiogenesis either by down-regulating VEGF and/or by inducing expression of thrombospondin 1 (Fig. 4) $(36,37)$.

Thrombospondin 1 (TSP1), a large $480 \mathrm{kd}$ trimeric protein, has been found to inhibit endothelial proliferation and migration in assays in vitro (38). Although mice lacking TSP1 do not appear to have defects in vasculogenesis (39), potent antiangiogenic peptides have been isolated from the monomeric polypeptide of TSP1 (38). Besides antiangiogenesis, TSP1 is involved in attachment, spreading, and motility of several cell types. Until recently, little was known about the mechanisms of TSP1 action except that its binding to the endothelial surface receptor, CD36, was essential for inhibition of endothelial cell proliferation (Fig. 4) (40). Investigators have recently shown that inhibition of angiogenesis and the induction of apoptosis by TSP1 requires the sequential activation of CD36, p59fyn, caspase-3 like proteases, and p38 mitogen-activated protein kinases (41). The roles of TSP1 and 2 in physiologic processes are at present unknown.

Thrombospondin 2 (TSP2) has high structural similarity to TSP1. In contrast to the normal vasculature observed in TSP1 null mice, mice lacking TSP2 have a significant increase in the number of blood vessels (42). Further evidence supporting a role in angiogenesis for TSP2 is its strong inhibition of endothelial proliferation (43). Although p53 induces the transcription of TSP1, it is unknown whether $\mathrm{p} 53$ induces TSP2.

Several studies have correlated the presence of wild-type p53 and increased levels of TSP1 with an antiangiogenic effect on tumors. Loss of functional p53 in small cell lung cancer specimens correlates with increases in VEGF (44). In addition, there is evidence to suggest that p53 could affect the growth of the tumor by inducing an antiangiogenic protein, TSP1. Interestingly, lower TSP1 levels in a variety of cell lines correlate with a more malignant phenotype (45). The MDA-MB-435 cell line, a very aggressive and metastatic breast cancer line when injected in nude mice, secretes the lowest levels of TSP1 when compared to less malignant breast cell lines. Similar to TSP1, an inverse relationship has been found between the levels of TSP2 and progression/vascularity of the tumor (46-48).

\section{E. Angiostatin and endostatin.}

Angiostatin and endostatin, both potent polypeptide antiangiogenic inhibitors of tumors, are proteolytic products of plasminogen and collagen XVIII, respectively $(49,50)$. Neither fulllength plasminogen nor collagen XVIII has any antiangiogenic activity. In angiostatin, the 
antiangiogenic activity is confined to the first three of the four kringle structures. Furthermore, the $2^{\text {nd }}$ and $3^{\text {rd }}$ kringle domains of angiostatin are synergistic in their antiproliferative tumor activity (51). In contrast to angiostatin, the precise location of the antiangiogenic activity of endostatin is unclear. Indeed, there may be several domains important for the antiangiogenic activity of endostatin (52-54).

The roles that angiostatin or endostatin play in physiology is unknown. Interestingly, with the use of antibodies "endostatin" can be detected in the serum of individuals without any evidence of tumors. It is possible that endostatin has a prophylactic function in preventing tumorigenesis. Alternatively, since full-length collagen XVIII (which contains endostatin) has no antiangiogenic activity (50) and can be detected by the polyclonal antibody to endostatin, the "endostatin" that is detected in the serum may not represent functional endostatin. This was suggested by Hefler and colleagues who found no difference in endostatin levels in patients with uterine cancer of various stages and aggressiveness (55).

Recently, investigators have found that angiostatin binds tightly to an ATP synthase on the endothelial cell surface (56). These receptors are specifically expressed on mitogenic endothelial cells, which may explain why there are few side effects with angiostatin. The antiproliferative effect of angiostatin was decreased by as much as $90 \%$ in the presence of anti-alpha-subunit ATP synthase antibody. At least part of the mechanism of action of angiostatin may be through this cell surface receptor. No receptor has yet been identified for the endostatin polypeptide.

Interestingly, a few tumors have enzymatic activity that generates angiostatin or endostatin $(49,50,57,58)$. It has been speculated that these proteins are mobilized to regulate carefully the angiogenic responses present in tumors.

\section{F. Antithrombin III}

Antithrombin III (AT), a plasma serpin, is a 58-kD glycoprotein (59) that is the principal inhibitor of thrombin and the blood-clotting proteinase factor Xa $(60,61)$. Antithrombin is relatively inactive as an inhibitor of coagulation proteases until it binds to the heparin side chains that line the microvasculature. The binding of heparin-like molecules to AT results in the proteolytic cleavage of AT at its $\mathrm{C}$-terminal end, which confers antiangiogenic activity to AT (62). It has been hypothesized that the cleaved AT with an altered conformation ("relaxed" AT) can assume a new antiangiogenic function by either binding to cell surface receptors or to the extracellular binding proteins. Although these data provide evidence that the clotting and fibrinolytic pathways are directly involved in the regulation of angiogenesis, further experiments are required to substantiate this interesting association.

The antitumor efficacy of antithrombin III was recently demonstrated in a pre-clinical study. By selective in vivo passage of a small cell lung cancer, O'Reilly and colleagues isolated a potent antiangiogenic form of antithrombin III with a "relaxed" conformation (62). It is unclear if the antiangiogenic form of antithrombin III has any role in most tumors. Nevertheless, the relaxed form of AT has been found to inhibit markedly tumor growth in mouse models. Compared to angiostatin and endostatin, antithrombin III is a significantly more potent tumor agent on a molar basis. Although AT is a promising antiangiogenic 
polypeptide, there are no gene therapy studies with this agent that have demonstrated antitumor efficacy.

\section{G. Cytokines}

Several cytokines including IL-12, Platelet factor 4 (PF-4) and IP10 have been associated with an anti-angiogenic effect. IL-12, an inflammatory cytokine, has a number of diverse biological functions. It has been demonstrated that IL-12 can inhibit angiogenesis and reduce tumor growth (63), and that this angiostatic response can be inhibited by blocking antibodies to IFN- $\gamma$, suggesting that IFN- $\gamma$ mediates the antiangiogenic component of IL-12. It has been further hypothesized that IP-10, an angiostatic protein induced by INF- $\gamma$, may mediate IL-12 effects on angiogenesis $(64,65)$.

Platelet factor 4 (PF-4) and IP10 belong to a family of C-X-C chemokines. These are heparin-binding basic proteins with well-characterized functions in tissue repair and inflammation $(22,66)$. These proteins inhibit proliferation and migration of endothelial cells $(67,68)$. Although they were initially thought to be angiostatic because of their ability to bind heparin, a mutated form of PF-4 lacking the heparin-binding domain showed angiostatic properties equivalent to those of the natural peptide. It now appears that the mechanism involves decreased receptor binding of VEGF and FGF2 (69).

Although there is no current role for IL-12 and PF-4 in tumor biology, administration of these cytokines does inhibit tumor growth in a mouse model $(70,71)$. While both IL-12 and PF-4 appear to inhibit tumor growth by an antiangiogenic mechanism, IL-12 also inhibits tumor growth by the recruitment of specific immune effector cells.

\section{H. Pigment Endothelial Derived factor (PEDF)}

PEDF appears to play an important role in preventing vessels from invading the cornea and the vitreous of the eye. PEDF is produced by retinal cells and its levels are directly correlated with oxygen concentrations (72). Loss of expression may play a role in ischemic conditions such as diabetic retinopathy and cancer. Fetal expression has not been studied, but PEDF is up-regulated 18 days postnatally in the pigment endothelial layer. In an endothelial migration assay, PEDF was a more potent inhibitor than angiostatin, thrombospondin 1, or endostatin. Nevertheless, the half-life of antiangiogenic inhibitors in vivo may be more important in determining their potency (63). No known antiangiogenic functions in tumors have yet been described for PEDF.

\section{Tissue inhibitors of Metalloproteinases (TIMPS)}

The matrix metalloproteinases (MMPs) are a family of secreted and membrane-bound zincendopeptidases; these enzymes can together degrade all the components of the extracellular matrix. MMPs are thought to be essential for the diverse invasive processes of angiogenesis and tumor metastasis. Counterbalancing the MMPs are the tissue inhibitors of metalloproteinases (TIMPS). TIMPS are naturally occurring proteins that specifically inhibit matrix metalloproteinases, thus maintaining balance between matrix destruction and formation. An imbalance between MMPs and the associated TIMPS can alter the physiologic angiogenic processes. This is demonstrated in Sorsby's fundus dystrophy, a 
genetic disorder in which mutations occur in TIMP-3. In this disease, inappropriate neovascularization of the choroidal layer is a prominent phenotypic feature (73).

To date, several studies have demonstrated that there is a close association between expression of various members of the MMP family by tumors and their proliferative and invasive behavior. Furthermore, inhibitors of metalloproteinases (TIMP 1, 2, and 3) have been shown to reduce tumor-induced angiogenesis in experimental systems. Although TIMPS may not be suitable for pharmacological applications due to their short half-life in vivo, two synthetic, low molecular weight MMP inhibitors (Batimastat and Marimastat) have been found to have antitumor activity (74).

\section{Applications and Mechanisms: Anti-Angiogenic Proteins in Gene Therapy}

The previous section discussed many angiogenic and antiangiogenic factors that may be useful in developing effective antiangiogenic strategies toward cancer. In this section, we will discuss the various antiangiogenic genes that investigators have thus far used in preclinical and clinical trials (Table II).

\section{A. The tumor suppressor, p53}

Although p53 has long been considered to inhibit tumor cell growth by altering the regulation of the cell cycle or apoptosis pathways, it is likely that there may be other mechanisms to explain tumor inhibition with p53 gene therapy. A bystander effect has been suggested for the observed difference between the relatively low transfection efficiency of the tumors with p53 and the reduction of tumor growth. Tumor inhibition mediated by gene therapy carriers expressing p53 appears to be due in part to angiogenesis inhibition. We determined that liposomes in complex with a plasmid encoding p53 inhibited tumor growth in a mouse model (75). We subsequently discovered that blood vessel density was reduced with this therapy (76). Other studies with liposomes carrying p53 plasmids have also demonstrated reduction in tumor growth in mouse models $(77,78)$. Besides liposomes, adenoviral and retroviral carriers expressing the p53 gene significantly reduced tumor growth and blood vessel density $(79,80)$. Moreover, adenoviral vectors expressing p53 significantly reduced VEGF levels within tumors. p53 may also decrease angiogenesis by inhibiting the cell cycle and/or enhancing apoptosis of the endothelial cells (76), inhibiting differentiation of endothelial cells (79), or by inducing the antiangiogenic protein, thrombospondin 1 (81).

\section{B. Inhibitory Polypeptides with an Extracellular Site of Action}

Several antiangiogenic peptides have potential antitumor efficacy, including laminin peptide, thrombospondin 1 and its peptides, a polypeptide fragment of prolactin, PF-4, IL-12, angiostatin, endostatin, and antithrombin III. Of these, gene therapy with PF-4, IL-12, thrombospondin 1, angiostatin, and endostatin have shown antitumor activity in a mouse model (10-12, 39, 48, 64, 82-85). Although these proteins have different mechanisms of action as discussed above, we consider them in one group because they probably all act extracellularly. 
i. Thrombospondin-In vitro experiments in which TSP1 was used to reduce endothelial cell growth show conflicting results. Nonetheless, peptides isolated from thrombospondin 1 clearly have antiangiogenic effects in vitro (38), but surprisingly, there have been no published reports demonstrating that these natural peptides have antitumor activity in vivo. It is unclear if the reduced functional activity of these peptides in vivo is due to a short half life. However, synthetic antiangiogenic thrombospondin peptides in the Dconformation do exhibit in vivo antitumor activity (18). In contrast to peptide therapy, three studies have suggested that antiangiogenic gene therapy with TSP1 or peptides derived from TSP1 exhibit antitumor activity $(46,83,84)$. Initially, an ex vivo study demonstrated that a tumor clone expressing high levels of TSP1 peptide reduced tumor growth (84). Recently, an ex vivo study showed that tumor clones expressing TSP2 had significantly more antitumor efficacy than clones expressing TSP1. More impressively, tumor clones expressing TSP1 and 2 were synergistic in their antitumor efficacy as demonstrated by the complete lack of tumor growth (46). In addition, investigators have demonstrated that p53 and an antiangiogenic peptide of TSP1 in complex with liposomes were synergistic in their inhibition of tumors (83). These liposome:DNA complexes were delivered intravenously at a site distant from the tumor.

ii. Angiostatin and Endostatin-It has been suggested that the half-life of antiangiogenic proteins may be the main determinant of their antitumor efficacy. Gene therapy offers the advantage of producing these proteins over an extended period of time and prolonging the effective 'half-life' of these proteins. Thus, gene therapy by delivery of shortlived proteins such as TSP1 would be expected to be advantageous compared to peptide therapy alone. Gene therapy delivery of some polypeptides, however, has not been as effective as the direct administration of these polypeptides to the tumor-bearing mice. For example, both angiostatin and endostatin polypeptides have shown marked inhibition of a variety of tumors in animal models. In one particularly dramatic experiment, tumors with a mean size of $500 \mathrm{~mm}^{3}$ were completely eliminated after therapy with the endostatin polypeptide. There was also no evidence of resistance developing to endostatin in these tumor-bearing mice.

In contrast, several gene therapy studies with angiostatin and endostatin have demonstrated only modest antitumor efficacy in animal models $(11,12,85)$. Therefore, the antitumor efficacy of the gene therapy approach has been far less effective than the polypeptide therapy. The most obvious reason for this is that systemic levels of endostatin and angiostatin after gene therapy are lower than are those after direct administration of these polypeptides. High extracellular levels of endostatin and angiostatin polypeptides are required to reduce tumor growth. With in vitro angiogenic assays, endostatin levels of $125 \mathrm{ng} / \mathrm{ml}$ are required to inhibit endothelial cell growth. Although these in vitro and in vivo results may not be easily translated to the gene therapy studies, they do suggest that high levels of these proteins are necessary for significant inhibition of tumor growth. Thus, although the approach of gene therapy with antiangiogenic polypeptides is relatively straightforward (at least in animal models), achieving adequate levels of the gene product remains a significant obstacle. 
iii. PF-4-An adenovirus expressing the antiangiogenic peptide PF-4 (82) was found to inhibit endothelial cell proliferation specifically in vitro. More importantly, the vectormediated PF4 transduction inhibited tumor growth of established gliomas and prolonged animal survival. This was the first report showing the efficacy of antiangiogenic gene therapy on established tumors.

iv. TIMPS-Although TIMPS may have half-lives that are too short for them to be administered as proteins, gene therapy may prolong delivery of these proteins. Nevertheless, the genes encoding these proteins should probably be delivered in close proximity to the tumor to enhance their efficacies. Investigators have discovered that adenovirus-mediated overexpression of TIMP-1, 2, and 3 inhibited invasion of several different tumor cells through artificial basement membrane (86). Nevertheless, only TIMP-3 promoted apoptosis, suggesting that this factor may be more effective in reducing tumor growth than either TIMP-1 or 2. To our knowledge, in vivo gene therapy with Timps has not reported $(86,87)$.

\section{Truncated receptors- VEGFR2, VEGFR1, sVEGFR1, Tie2}

An early watershed study demonstrating the utility of antiangiogenic gene therapy targeted the VEGF receptor, VEGFR2. Co-administration of a truncated VEGF receptor (VEGFR2) with tumor cells was shown to inhibit the growth of the tumor (6). It is likely that this retrovirus-transduced receptor acts through a dominant-negative mechanism to inhibit the wild-type VEGF receptor. The study not only showed the potential of this approach but also demonstrated that VEGF has an essential role in tumor development. More recently, investigators have demonstrated that antiangiogenic therapy with the truncated VEGF receptor suppressed angiogenesis and intracerebral glioma tumor growth (88). Survival time of rats with intracerebral tumors increased with treatment. In these two studies, the truncated VEGFR2 targeted the wild-type receptor of the transfected cell. However, the clinical utility of this approach is somewhat limited owing to the low transfection efficiencies of the vector delivery systems. One method to circumvent the low transfection efficiency of vector delivery systems is to engineer a secreted therapeutic protein. This was demonstrated by Goldman and colleagues (9) where tumor cells transduced with a secreted soluble VEGF receptor (sVEGFR1) inhibited implantation of a primary tumor. Furthermore, when tumor cells expressing high levels of sVEGFR1 were injected intravenously, mice displayed fewer lung metastases.

In addition to the VEGF and VEGF receptors, other receptors have been targeted for antiangiogenic gene therapy. An adenovirus expressing a soluble Tie 2 receptor was recently shown to inhibit tumor growth when injected intravenously, by binding to angiopoietin 2 (8). With plasma concentrations of the soluble recombinant Tie 2 receptor exceeding $1 \mathrm{mg} / \mathrm{ml}$ for an 8-day period, established tumors treated by the intravenous injectable route in this study were significantly reduced. In addition, co-administration of the adenovirus-Tie 2 vector with tumor cells greatly reduced the number of lung metastases. A potential disadvantage of this therapy is that the adenovirus-Tie 2 construct may also inactivate angiopoietin 1, a protein known primarily for its ability to stabilize blood vessels. 


\section{Antisense approaches}

An alternative approach to reduce tumor growth is to target growth factors with antisense strategies. Antisense gene therapy has been used to reduce FGF2 levels within a tumor and to decrease the tumor size (89). In addition, stable transfection of tumor cells with plasmids expressing antisense VEGF did not affect the growth of tumor cells in vitro but reduced tumor growth in vivo (7). Targeting VEGF with a retrovirus producing cell line has also prolonged survival of a glioma-bearing rat model (90). VEGF levels may also be downregulated with antisense approaches directed toward the adenosine $2 \mathrm{~B}$ receptor. As discussed previously, adenosine induces VEGF $m R N A$ and protein after binding to the adenosine $2 \mathrm{~B}$ receptor. Although this approach has not shown antitumor efficacy in vivo, investigators have found that mitogenesis of endothelial cells is reduced with antisense oligonucleotides. The major difficulty of targeting VEGF in vivo with antisense approaches is that if most of the VEGF is expressed in tumor cells and not the tumor endothelial cells, it may be difficult to achieve adequate expression of the antisense construct.

\section{Routes of administration for antiangiogenic genes}

As with other gene therapy approaches, the major limitation of antiangiogenic gene therapy lies in the choice of vector delivery systems. Although there has been an incremental improvement in these systems, precisely when an adequate vector system will be developed for antiangiogenic genes is difficult to forecast. Since proteins of antiangiogenic gene therapy may require secretion, several tissues other than tumor endothelial cells can express these proteins. Consequently, secretion of antiangiogenic proteins allows the route of gene delivery to be varied. In this section, the advantages (and disadvantages) and recent advances of major delivery systems will be examined in terms of the route of delivery (for reviews on non-viral and viral vectors, see $(91,92))$. The routes of delivery for antiangiogenic genes include intravenous, intratumoral and intramuscular injection. In animal models, all three modes of delivery have demonstrated antitumor efficacy with antiangiogenic genes.

\section{A. Intravenous}

Intravenous injections of both viral and non-viral vectors expressing antiangiogenic genes have demonstrated antitumor efficacy in animal models. Three studies have used adenovirus to express antiangiogenic genes and their gene products $(8,9,80)$. Besides being the most common viral vector in current use, adenovirus vectors were probably selected because intravenous injection of adenovirus results in impressively high transfection rates in the liver, compared to other viral or non-viral vectors. It is not known from these studies how much antiangiogenic protein is expressed in the tumor endothelial cells. In one report, an antiangiogenic protein, the truncated Tie 2 receptor, was expressed at levels above $1 \mathrm{mg} / \mathrm{ml}$ that were sustained for nearly a week, but there was only moderate reduction in the tumor size. Similarly, two other studies with adenoviral vectors expressing either angiostatin or sVEGFR1 also showed only moderate effects on tumor growth. The most significant problem with adenoviral vectors is that they provoke a strong immune response in humans. In pre-clinical studies, tumor-bearing animals were injected only once with the adenoviral carrier to minimize an immunological response. 
Considerable effort has been expended to avoid immunological and other toxic responses. Second, third, and now fourth generation adenoviral systems have been developed and the expression of genes has been progressively prolonged. Since these newer generation viral vectors contain minimal amounts of viral DNA within them, the immunological reactions toward these viral vectors appear to be reduced; pegylation of adenoviruses has resulted in a further reduction in immunological reactions toward these vectors. Although initial results with these pegylated viral vectors appear promising, further studies are needed before determining the effect of these viruses on transfection (93). Despite these pre-clinical advances in the adenoviral delivery vector, concerns about the safety of adenovirus have only been heightened with the death of a patient due to the therapy. It seems likely that lessons learned from the use of adenoviral vectors can be applied to other viral vectors such as AAV and lentivirus.

Non-viral vectors have also demonstrated antitumor efficacy when injected intravenously with a plasmid encoding endostatin. In one pre-clinical study with cationic liposomes as a carrier, moderate reduction in the tumor size of mice bearing MDA-MB-435 cells was observed after the third injection (11). In addition to liposomes, which are the most commonly used non-viral delivery system, several cationic polymers such as polyethylenimine or poly-L-lysine have shown effective DNA transfer in vivo $(94,95)$. The most promising aspect of intravenous administration of non-viral vectors is their low toxicity. In addition, non-viral vectors such as cationic liposomes, when administered intravenously, can selectively target the mitogenic tumor endothelial cells rather than quiescent endothelial cells (96). Adding ligands that specifically target the tumor endothelial cells may further increase the specificity and efficacy of cationic liposomes $(97,98)$. Three significant limitations hamper the in vivo use of these non-viral vectors, however. One is the low in vivo transfection efficiency of organs or vessels within organs. Efforts have been made to increase the in vivo transfection of these vectors by modifying the cationic lipids or adding cationic polymers to these liposomes. Both of these modifications appear to increase the transfection of liposomes significantly (99-101). A second significant limitation of these non-viral vectors is that they have half-lives of only a few minutes in the blood stream. The potential long-term expression of the antiangiogenic protein mitigates to some extent against this limitation. Nevertheless, an increase in the half-life of these vectors may enhance antitumor efficacy when the primary targets of transfection are the mitogenic endothelial cells of the tumor. Since angiogenesis is a continuing process within the tumor, prolonging the half-life of the vectors might increase the peritumoral level of the antiangiogenic protein. The half-lives of cationic non-viral vectors have been increased at least in part by pegylating the surface of these vectors $(101,102)$. Although enhancement of in vivo transfection and the increase in the liposome half-life appear promising, it remains to be determined whether these modifications will increase the antitumor efficacy. The third problem with non-viral vectors is a non-specific antitumor effect that has been seen with liposome:DNA complexes (76). This antitumor effect, which occurs in the absence of a therapeutic gene product being expressed, may be mediated by an immunostimulatory response to the liposome:DNA complexes (103). Unfortunately, we have found that the antitumor immunostimulatory effect is inversely correlated to the antitumor effect of the therapeutic product (76). It is not known whether this non-specific effect occurs with other non-viral delivery systems such as 
polymers (e.g. polyethyleneimine, Superfect) (104-107). Despite these problems, we expect that non-viral vectors will have a major role in targeting vessels of tumor.

\section{B. Intramuscular Somatic}

Blezinger and colleagues have recently shown the utility of somatic antiangiogenic gene therapy by injecting a cationic polymer (PVP)-endostatin plasmid complex into mouse muscle (12). The tumors in these mice were significantly reduced and measurable levels of endostatin were detected in the blood stream. This is the only carrier thus far that has demonstrated the effectiveness of antiangiogenic therapy with intramuscular injections. Because of the prolonged expression of plasmids within muscle, we anticipate that this will become a common approach for administering antiangiogenic genes.

Several viral and non-viral delivery systems when injected intramuscularly may result in high levels of expression of antiangiogenic genes. Although it has not been determined whether systemic levels of an antiangiogenic protein with adeno-associated virus as a carrier can reduce tumor growth on a short- or long-term basis, it has been established that longterm expression of erythropoietin can be achieved by multiple injections into mouse muscles (108). The erythropoietin produced by gene therapy stimulated the hematocrit in these mice for nearly 6 months. Lentiviruses are another potential viral vector that may decrease tumor growth with intramuscular injections. The heralded advantage of lentivirus is that it can transfect both mitogenic and quiescent cells (109-111), although one report has cast doubt on this potential advantage (112). Both AAV and lentiviral delivery systems are significantly less immunogenic than are the adenoviruses. Nevertheless, it is not clear whether the immunogenicity of AAV or lentiviruses will be low enough to achieve long term elevated levels of antiangiogenic proteins in humans.

Two additional delivery systems to the muscle have the advantage of high expression without the toxicity of lipids, polymer, or viral carriers. Injection of naked DNA into muscle has been shown to express the gene product for prolonged periods of time (113). In addition, electroporation can significantly enhance the expression of a gene product compared to naked DNA injections alone, without subjecting the animal to the toxic effects of the vehicle (114). Nevertheless, particular care must be taken to prevent or minimize immunogenic or immunostimulatory responses in delivery systems with long term expression of antiangiogenic genes.

\section{Intratumoral}

Most of the carriers (liposomes, polymers, adenovirus, lentivirus, electroporation) discussed in the intramuscular injection section will be applicable to intratumoral injections of antiangiogenic genes. Except for lentiviruses, most retroviruses can only transduce mitogenic cells effectively. On certain occasions this property is desirable because the vector carrying the antiangiogenic gene will transduce the mitogenic cells of the tumor without transducing the normally quiescent surrounding tissue. Local injections of retroviruses expressing VEGFR2 and PF4 proteins have resulted in tumor reduction $(6,82,88)$. In addition, locally injected liposomes in complex with angiostatin- or endostatin-containing plasmids also reduced the growth of a human breast cancer line in a mouse model (11). 


\section{Future Directions.}

The utility of antiangiogenic gene therapy in a clinical setting will depend in large part on developing vectors with minimal toxicity and with increased in vivo transfection efficiency. Until these vectors are developed in pre-clinical models, clinical studies directed toward tumor inhibition will continue to yield marginal results. For a decade, there have been tremendous, and perhaps unrealistic expectations for gene therapy approaches. With the lack of success in clinical trials followed by the recognition that gene therapy may have significant side effects, there is now the risk of undue cynicism toward the field. We hope that more realistic expectations will prevail and engender the development of new gene therapy vectors and approaches toward neoplastic and non-neoplastic diseases.

One of the new gene therapy approaches that has attracted interest in the last few years is targeting of the blood vessels of the tumor. This approach is appealing since tumor vessels are readily accessible to therapy. Several studies have now demonstrated the "proof of principle" of antiangiogenic gene therapy with local and/or systemic administration. With the discovery of new antiangiogenic genes, more potent therapies are anticipated. Furthermore, combinations of antiangiogenic genes are currently being explored and will undoubtedly yield more potent antitumor responses. We believe that progressive improvement of antiangiogenic therapy against cancer and other angiogenesis-based diseases will continue as more potent antiangiogenic genes and vector delivery systems are defined. It must be remembered, however, that even though pre-clinical and clinical trials may demonstrate significant efficacy, this does not ensure that antiangiogenic gene therapy will usurp its counterpart, antiangiogenic peptide therapy. The success of antiangiogenic gene therapy compared to peptide/protein therapy will be contingent on several factors including, for example, antitumor efficacy, toxicity, half-life of protein, and costeffectiveness. Nevertheless, antiangiogenic gene therapy has a number of potential advantages compared to peptide therapy. These advantages, which are dependent on the delivery systems and the route of delivery, include prolonged expression of the gene product, the ability to target the tumor or its vessels specifically, and the ability to control localization of the product. We believe that at least some of the potential advantages that antiangiogenic gene therapy has over its peptide/protein counterpart will be realized.

\section{Acknowledgments}

We are grateful to Drs. Amy Fulton and Antonino Passaniti for their careful reading and useful comments concerning the manuscript. The National Institutes of Health (CA70394) supported this work.

Supported by the National Institutes of Health (CA70394).

\section{References}

1. Folkman J Tumor angiogenesis: Therapeutic implications, N. Eng. J. Med 333: 1757-1763, 1971.

2. Folkman J The vasculization of tumors, Sci. Am 234: 58-73, 1976. [PubMed: 1273568]

3. Folkman J Antiangiogenic gene therapy, Proc. Natl. Acad. Sci. USA 95: 9064-9066, 1998. [PubMed: 9689032]

4. Kerbel RS Inhibition of tumor angiogenesis as a strategy to circumvent acquired resistance to anticancer therapeutic agents, Bioessays. 13: 31-36, 1991. [PubMed: 1722975] 
5. Boehm T, Folkman J, Browder T, and O'Reilly MS Antiangiogenic therapy of experimental cancer does not induce acquired drug resistance [see comments], Nature. 390: 404-407, 1997. [PubMed: 9389480]

6. Millauer B, Shawver LK, Plate KH, Risau W, and Ullrich A Glioblastoma growth inhibited in vivo by a dominant-negative Flk-1 mutant, Nature. 367: 576-579, 1994. [PubMed: 8107827]

7. Saleh M, Stacker SA, and Wilks AF Inhibition of growth of C6 glioma cells in vivo by expression of antisense vascular endothelial growth factor sequence, Cancer Res. 56: 383-401, 1996.

8. Lin P, Buxton JA, Acheson A, Radziejewski C, Maisonpierre PC, Yancopoulos GD, Channon KM, Hale LP, Dewhirst MW, George SE, and Peters KG Antiangiogenic gene therapy targeting the endothelium-specific receptor tyrosine kinase Tie2, Proc. Natl. Acad. Sci. USA 95: 8829-8834, 1998. [PubMed: 9671764]

9. Goldman CK, Kendall FL, Cabrera G, Soroceanu L, Heike Y, Gillespie GY, Siegal GP, Mao X, Bett AJ Huckle WR, Thomas KA, and Curiel DT Paracrine expression of a native soluble vascular endothelial growth factor receptor inhibits tumor growth, metastasis, and mortality rate, Proc. Natl. Acad. Sci. USA 95: 8795-8800, 1998. [PubMed: 9671758]

10. Griscelli F, Li H, Griscelli AB, Soria J, Opolon P, Soria C, Perricaudet M, Yeh P, and Lu H Angiostatin gene transfer: Inhibition of tumor growth in vivo by blockage of endothelial cell proliferation associated with a mitosis arrest, Proc. Natl. Acad. Sci. USA 95: 6367-6372, 1998. [PubMed: 9600971]

11. Chen QR, Kumar D, Stass SA, and Mixson AJ Liposomes complexed to plasmids encoding angiostatin and endostatin inhibit breast cancer in nude mice., Cancer Res. 59: 3308-3312, 1999. [PubMed: 10416583]

12. Blezinger P, Wang J, Gondo M, Quezada A, Mehrens D, French M, Singhai A, Sullivan S, Rolland A, Ralston R, and Min W Systemic inhibition of tumor growth and tumor metastases by intramuscular administration of the endostatin gene, Nat. Biotechnol 17: 623-632, 1999.

13. Breier $\mathrm{G}$, and Risau W The role of vascular endothelial growth factor in blood vessel formation, Trends in Cell Biol. 6: 454-456, 1996. [PubMed: 15157501]

14. Neufeld G, Cohen T, Genegrinovitch S, and Poltorak Z Vacular endothelial growth factor (VEGF) and its receptors, FASEB J. 13: 9-22, 1999. [PubMed: 9872925]

15. Dvorak HF, Brwon LF, Detmar M, and Dvorak AM Vascular permability factor?vascular endothelial growth factor, microvascular permeability, and angiogenesis, Am. J. Pathol 146: 10291039, 1995. [PubMed: 7538264]

16. Senger DR Commentary:molecular framework for angiogenesis. A complex web of interactions between extravasated plasma protein and endothelial cell proteins induced by angiogenic cytokines, Am. J. Pathol 149: 1-7, 1996. [PubMed: 8686733]

17. Grant MB, Tarnuzzer RW, Caballero S, Ozeck MJ, Davis MI, Spoerri PE, Feoktistov I, Biaggioni I, Shryock JC, and Belardinelli L Adenosine receptor activation induces vascular endothelial growth factor in human retinal endothelial cells, Circ. Res 85: 699-706, 1999. [PubMed: 10521243]

18. Guo NH, Krutzsch HC, Inman JK, Shannon CS, and Roberts DD Antiproliferative and antitumor activities of D-reverse peptides derived from the second type-1 repeat of thrombospondin-1, J. Pept. Res 50: 210-221, 1997. [PubMed: 9309585]

19. Kendall RL, Wang G, and Thomas KA Identification of a natural soluble form of the vascular endothelial growth factor receptor, FLT-1, and its heterodimerization with KDR, Biochem. Biophys. Res. Commun 226: 324-328, 1996. [PubMed: 8806634]

20. Roeckl W, Hecht D, Sztajer H, Waltenberger J, Yayon A, and Weich HA Differential binding characteristics and cellular inhibition by soluble VEGF receptors 1 and 2, Exp. Cell Res 241: 16170, 1998. [PubMed: 9633524]

21. Soker S, Takashima S, Miao HQ, Neufeld G, Klagsbrun M Neuropilin-1 is expressed by endothelial and tumor cells as an isoform- specific receptor for vascular endothelial growth factor, Cell. 92: 735-745, 1998. [PubMed: 9529250]

22. Colville-Nash PR, and Willoughby DA Growth factors in angiogenesis:current interest and therapeutic potential, Mol. Med 3: 14-23, 1997. 
23. Kim KJ, Li B, Winer J, Armanini M, Gillett N, Phillips HS, Ferrara N Inhibition of vascular endothelial growth factor-induced angiogenesis suppresses tumour growth in vivo, Nature. 362: 841-844, 1993. [PubMed: 7683111]

24. Gimbrone MA, Jr., Leapman SB, Cotran RS, and Folkman J Tumor dormancy in vivo by prevention of neovascularization, J. Exp. Med. 136: 261-276, 1972. [PubMed: 5043412]

25. Gimbrone MA, Jr., Cotran RS, Leapman SB, and Folkman J Tumor growth and neovascularization: an experimental model using the rabbit cornea, J. Natl. Cancer Inst 52: 413-427, 1974. [PubMed: 4816003]

26. Holash J, Maisonpierre PC, Compton D, Boland P, Alexander CR, Zagzag D, Yancoupoulos GD, and Wiegand SJ Vessel cooption, regression, and growth in tumors mediated by angiopoietins and VEGF, Science. 284: 1994-1998, 1999. [PubMed: 10373119]

27. Hanahan D Signaling vascular morphogenesis and maintenance, Science. 277: 48-50, 1997. [PubMed: 9229772]

28. Friedlander M, Brooks PD, Shaffer RW, Kincaid DM, Varner JA, and Cheresh DA Definition of two angiogenic pathways by distinct av integrins., Science. 270: 1500-1502, 1995. [PubMed: 7491498]

29. Risau W What, if anything, is an angiogenic factor?, Cancer Metastasis Rev. 15: 149-151, 1996. [PubMed: 8842485]

30. Dedhar S, Hannigan GE, Rak J, and Kerbel RS The extracellular envionment and cancer In: Hill I. F. T. a. R. P. (ed.) The Basic Science of Oncology, Third edition, pp. 197-218. New York: McGraw-Hill, 1998.

31. Matsuzaki K, Yoshitake Y, Matuo Y, Sasaki H, Nishikawa K Monoclonal antibodies against heparin-binding growth factor II/basic fibroblast growth factor that block its biological activity: invalidity of the antibodies for tumor angiogenesis., Proc. Natl. Acad. Sci. USA 86: 9911-9915, 1989. [PubMed: 2481318]

32. Nguyen M, Watanabe H, Budson AE, Richie JP, and Folkman J Elevated levels of the angiogenic peptide basic fibroblast growth factor in urine of bladder cancer patients, J. Natl. Cancer Inst 85: 241-242, 1993. [PubMed: 8423630]

33. Nguyen M, Watanabe H, Budson AE, Richie JP, Hayes DF, and Folkman J Elevated levels of an angiogenic peptide, basic fibroblast growth factor, in the urine of patients with a wide spectrum of cancers, J. Natl. Cancer Inst 86: 328-329, 1994. [PubMed: 7508517]

34. Choi J and Donehower LA p53 in embryonic development: maintaining a fine balance, Cell Mol. Life Sci 55: 38-47, 1999. [PubMed: 10065150]

35. Xiang H, Hochman DW, Saya H, Fujiwara T, Schwartzkroin PA, and Morrison RS Evidence for p53-mediated modulation of neuronal viability, J. Neurosci 16: 6753-6765, 1996. [PubMed: 8824316]

36. Volpert OV, Dameron KM, and Bouck N Sequential development of an angiogenic phenotype by human fibroblasts progressing to tumorigenicity, Oncogene. 14: 1495-1502, 1997. [PubMed: 9136993]

37. Dameron KM, Volpert OV, Tainsky MA, and Bouck N The p53 tumor suppressor gene inhibits angiogenesis by stimulating the production of thrombospondin, Cold Spring Harb. Symp. Quant. Biol 59: 483-489, 1994. [PubMed: 7587102]

38. Tolsma VS, Volpert OV, Good DJ, Frazier WA, Polverini PJ, and Bouck N Peptides derived form two separate domains of the matrix protein thrombospondin I have anti-angiogenic activity, J. of Cell Biol 122: 497-511, 1993. [PubMed: 7686555]

39. Lawler J, Sunday M, Thibert V, Duquette M, George EL, Rayburn H, and Hynes RO Thrombospondin-1 is required for normal murine pulmonary homeostasis and its absence causes pneumonia, J. Clin. Invest 101: 982-992, 1998. [PubMed: 9486968]

40. Dawson DW, Pearce SFA, Zhong R, Silverstein RL and Frazier RL CD36 mediates the in vitro inhibitory effects of thrombospondin-1 on endothelial cells, J. of Cell Biol. 138: 707-717, 1997. [PubMed: 9245797]

41. Jiminez B, Volpert OV, Crawford SE, Febbraio M, Silverstein RL, and Bouck N Signals leading to apoptosis-dependent inhibition of neovascularization by thrombospondin-1, Nat. Med 6: 41-48, 2000. [PubMed: 10613822] 
42. Kyriakides TR, Zhu YH, Smith LT, Bain SD, Yang Z, Lin MT, Danielson KG, Iozzo RV, LaMarca M, McKinney CE, Ginns EI, and Bornstein P Mice that lack thrombospondin 2 display connective tissue abnormalities that are associated with disordered collagen fibrillogenesis, an increased vascular density, and a bleeding diathesis, J. Cell Biol 140: 419-430, 1998. [PubMed: 9442117]

43. Volpert OV, Tolsma SS, Pellerin S, Feige JJ, Chen H, Mosher DF, and Bouck N Inhibition of angiogenesis by thrombospondin-2, Biochem. Biophys. Res. Commun 217: 326-332, 1995. [PubMed: 8526929]

44. Giatromanolaki A, Koukourakis MI, Kakolyris S, Turley H, O’Byrne K, Scott PA, Pezzella F, Georgoulias V, Harris AL, and Gatter KC Vascular endothelial growth factor, wild-type p53, and angiogenesis in early operable non-small cell lung cancer, Clin. Cancer Res 4: 3017-3024, 1998. [PubMed: 9865915]

45. Zabrenetzky V, Harris CC, Steeg PS and Roberts DD Expression of the extracellular matrix molecule Thrombospondin inversely correlates with malignant progression in melanoma, lung, and breast carcinoma, Int. J. Cancer 59: 191-195, 1994. [PubMed: 7927918]

46. Streit M, Riccardi L, Velasco P, Brown LF, Hawighorst T, Bornstein P, and Detmar M Thrombospondin-2: A potent endogenous inhibitor of tumor growth and angiogenesis, Proc. Natl. Acad. Sci. USA 96: 14888-14893, 1999. [PubMed: 10611308]

47. Tokunaga T, Nakamura M, Oshika Y, Abe Y, Ozeki Y, Fukushima Y, Hatanaka H, Sadahiro S, Kijima H, Tsuchida T, Yamazaki H, Tamaoki N, and Ueyama Y Thrombospondin 2 expression is correlated with inhibition of angiogenesis and metastasis of colon cancer, Br. J. Cancer 79: 354359, 1999. [PubMed: 9888480]

48. Kazuno M, Tokunaga T, Oshika Y, Tanaka Y, Tsugane R, Kijima H, Yamazaki H, Ueyama Y, and Nakamura M Thrombospondin-2 (TSP2) expression is inversely correlated with vascularity in glioma, Eur. J. Cancer 35: 502-506, 1999. [PubMed: 10448307]

49. O’Reilly MS, Holmgren L, Shing Y, Chen C, Rosalind RA, Moses M, Snae WS, Cao Y, Sage EH, and Folkman J Angiostatin: a novel angiogenesis inhibitor that mediates the suppression of metastases by a Lewis lung carcinoma, Cell. 79: 315-328, 1994. [PubMed: 7525077]

50. O’Reilly MS, Boehm T, Shing Y, Fukai N, Vasios G, Lane WS, Flynn E, Birkhead JR, Olsen BR, and Folkman J Endostatin: an endogenous inhibitor of angiogenesis and tumor growth, Cell. 88: 277-285, 1997. [PubMed: 9008168]

51. Cao Y, Ji RW, Davidson D, Schaller J, Marti D, Sohndel S, McCance SG, O’Reilly MS, Linas M, Folkman J Kringle domains of human angiostatin. Characterization of the anti-proliferative activity on endothelial cells, J. Biol. Chem 271: 29461-29467, 1996. [PubMed: 8910613]

52. Boehm T, O’Reilly MS, Keouogh K, Shiloach J, Shapiro R, Folkman J Zinc-binding of endostatin is essential for its antiangiogenic activity, Biochem. Biophys. Res. Commun 252: 190-194, 1998. [PubMed: 9813168]

53. Sasaki T, Larsson H, Dreuger J, Salmiverta M, Claesson-Welsh L, Lindahl U, Hohenester E, and Timpl R Structural basis and potential role of heparin/heparan sulfate binding to the angiogenesis inhibitor endostatin, EMBO J. 18: 6240-6248, 1999. [PubMed: 10562536]

54. Yamaguchi N, Anand-Apte B, Lee M, Sasaki T, Fukai N, Shapiro R, Que I, Lowik C, Timpl R, Olsen BR Endostatin inhibits VEGF-induced endohtelial cell migration and tumor growth independently of zinc binding, EMBO J. 18: 4414-4423, 1999. [PubMed: 10449407]

55. Hefler L, Tempfer C, Kainz C, and Obermair A Serum concentrations of endostatin in pateints with vulvar cancer, Gynecol. Oncol 74: 151-152, 1999. [PubMed: 10385573]

56. Moser TL, Stack MS, Asplin I, Enghild JJ, Hojrup P, Everitt L, Hubchak S, Schnaper HW, and Pizzo SV Angiostatin binds ATP synthase on the surface of human endothelial cells, Proc. Natl. Acad. Sci. USA 96: 2811-2816, 1999. [PubMed: 10077593]

57. Gately S, Twardowski T, Stack S, Patrick M, Boggio L, Cundiff DL, Schnaper HW,. Madison L, Volpert O, Bouck N, Enghild J, Dwann HC, and Soff GA Human prostate carcinoma cells express enzymatic activity that converts human plaminogene to the angigogenesis inhibitor, angiostatin, Cancer Res. 56: 4887-4890, 1996. [PubMed: 8895739]

58. Gately S, Twardowski T, Stack S, Patrick M, Boggio L, Cundiff DL, Schnaper HW,. Madison L, Volpert O, Bouck N, Enghild J, Dwann HC, and Soff GA. The mechanim of cancer-mediated 
conversion of plasminogen to the angiogenesis inhibitor angiostatin., Proc. Natl. Acad. Sci. USA 94: 10868-10872, 1997. [PubMed: 9380726]

59. Bauer KA and Rosenberg RD Role of antithrombin III as a regulator of in vivo coagulation, Semin. Hematol 28: 10-18, 1991.

60. Jin L, Abrahams JP, Skinner R, Petitou M, Pike RN, and Carrell RW The anticoagulant activation of antithrombin by heparin, Proc. Natl. Acad. Sci. USA 94: 14683-8, 1997. [PubMed: 9405673]

61. Huntington JA and Gettins PG Conformational conversion of antithrombin to a fully activated substrate of factor Xa without need for heparin, Biochemistry. 37: 3272-3277, 1998. [PubMed: 9521646]

62. O'Reilly MS, Pirie-Shepherd S, Lane WS, and Folkman J Antiangiogenic activity of the cleaved conformation of the serpin antithrombin [see comments], Science. 285: 1926-1928, 1999. [PubMed: 10489375]

63. Voest EE, Kenyon BM, O'Reilly MS, Truit G, D'Amato RJ, and Folkman J Inhibition of angiogenesis in vivo by interleukin 12, J. of Natl. Cancer Inst 87: 581-586, 1995. [PubMed: 7538593]

64. Sgadari C, Angiolillo AL, and Tosato G Inhibition of angiogenesis by interleukin-12 is mediated by the interferon-inducible protein 10, Blood. 87: 3877-3882, 1996. [PubMed: 8611715]

65. Angiolillo AL, Sgadari C, and Tosato G A role for the interferon-inducible protein 10 in inhibition of angiogenesis by interleukin-12, Ann. N. Y. Acad. Sci 795: 158-167, 1996. [PubMed: 8958926]

66. Strieter RM, Polverini PJ, Arenberg DA, Kunkel SL The role of CXC chemokines as regulators of angiogenesis, Shock. 4: 155-160, 1995. [PubMed: 8574748]

67. Maione TE, Gray GS, Petro J, Hunt AJ, Donner AL, Bauer SI, Carson HF, and Sharpe RJ Inhibition of angiogenesis by recombinant human platelet factor- 4 and related peptides, Science. 247: 77-79, 1990. [PubMed: 1688470]

68. Angiolillo AL, Sgadari C, Taub DD, Liao F, Farber JM, Maheshwari S, Kleinman HK, Reaman $\mathrm{GH}$, and Tosato $\mathrm{G}$ Human interferon-inducible protein 10 is a potent inhibitor of angiogenesis in vivo, J. Exp. Med 182: 155-162, 1995. [PubMed: 7540647]

69. Gengrinovitch S, Greenberg SM, Cohen T, Gitay-Goren H, Rockwell P, Maione TE, Levi BZ, and Neufeld G Platelet factor-4 inhibits the mitogenic activity of VEGF121 and VEGF165 using several concurrent mechanisms, J. Biol. Chem 270: 15059-15065, 1995. [PubMed: 7797488]

70. Boggio K, Di Carlo E, Rovero S, Cavallo F, Quaglino E, Lollini PL, Nanni P, Nicoletti G, Wolf S, Musiani P, and Forni G Ability of systemic interleukin-12 to hamper progressive stages of mammary carcinogenesis in HER2/neu transgenic mice [In Process Citation], Cancer Res. 60: 359-64, 2000. [PubMed: 10667588]

71. Sharpe RJ, Byers HR, Scott CF, Bauer SI, and Maione TE Growth inhibition of murine melanoma and human colon carcinoma by recombinant human platelet factor 4, J. Natl. Cancer Inst 82: 848853, 1990. [PubMed: 1692094]

72. Dawson DW, Volpert OV, Gillis P, Crawford SE, Xu H-J, Benedict W, and Bouck NP Pigment epithelium-derived factor: a potent inhibitor of angiogenesis, Science. 285: 245-248, 1999. [PubMed: 10398599]

73. Anand-Apte B, Pepper MS, Voest E, Montesano R, Olsen B, Murphy G, Apte SS, and Zetter B Inhibition of angiogenesis by tissue inhibitor of metalloproteinase-3 [see comments], Invest. Ophthalmol. Vis. Sci 38: 817-823, 1997. [PubMed: 9112976]

74. Wojtowicz-Praga SM, Dickson RB, and Hawkins MJ Matrix metalloproteinase inhibitors, Invest. New Drugs 15: 61-75, 1997. [PubMed: 9195290]

75. Lesoon-Wood LA, Kim WH, Kleinman HK, Weintraub BD, and Mixson AJ Systemic gene therapy with 553 reduces growth and metastases of a mligangt human breast cancer in nude mice, Hum. Gene Ther 6: 395-405, 1995. [PubMed: 7612697]

76. Xu M, Kumar D, Srinivas S, DeTolla LJ, Yu SF, Stass SA, and Mixson AJ Parenteral Gene Therapy with p53 inhibits human breast tumors in vivo through a bystander mechanism without evidence of toxicity, Hum. Gene Ther 8: 177-185, 1996.

77. Hsiao M, Tse V, Carmel J, Tsai Y, Felgner PL, Haas M, and Silverberg GD Intracavitary liposomemediated p53 gene transfer into glioblastoma with endogenous wild-type p53 in vivo results in 
tumor suppression and long-term survival, Biochem. Biophys. Res. Commun 233: 359-364, 1997. [PubMed: 9144539]

78. Xu L, Pirollo KF, Tang WH, Rait A, and Chang EH Transferrin-liposome-mediated systemic p53 gene therapy in combination with radiation results in regression of human head and neck cancer xenografts, Hum. Gene Ther 10: 2941-2952, 1999. [PubMed: 10609655]

79. Riccioni T, Cirielli C, Wang X, Passaniti A, and Capogrossi MC Adenovirus-mediated wild-type p53 overexpression inhibits endothelial cell differentiation in vitro and angiogenesis in vivo, Gene Ther. 5: 747-754, 1998. [PubMed: 9747454]

80. Bouvet M, Ellis LM, Nishizaki M, Fujiwara T, Liu W, Bucana CD, Fang B, Lee JJ and Roth JA Adenovirus- mediated wild-type p53 gene transfer down-regulates vascular endothelial growth factor expression and inhibits angiogenesis in human colon cancer, Cancer Res. 58: 2288-2292, 1998. [PubMed: 9622060]

81. Liu Y, Thor A, Shtivelman E, Cao Y, Tu G, Heath TD, and Debs RJ Systemic gene delivery expands the repertoire of effective antiangiogenic agents, J. of Biol. Chem 274: 13338-13344, 1999. [PubMed: 10224095]

82. Tanaka T, Manome Y, Wen P, Kufe DW, and Fine HA Viral vector-mediated transduction of a modified platelet factor 4 cDNA inhibits angiogenesis and tumor growth, Nat. Med 3: 437-442, 1997. [PubMed: 9095178]

83. Xu M, Kumar D, Stass SA, and Mixson AJ Gene therapy with p53 and a fragment of thrombospondin I inhibits human breast cancer in vivo, Mol. Genet. and Metab 63: 103-109, 1998. [PubMed: 9562963]

84. Weinstat-Saslow D Z. VS, VanHourtte K, Frazier WA, Roberts DD, and Steeg PS Transfection of thrombospondin I complementary DNA into a human breast carcinoma cell line reduces primary tumor grosth, metastatic potential, and angiogenesis, Cancer Res. 54: 6504-6511, 1994. [PubMed: 7527299]

85. Cao Y, O’Reilly MS, Marshall B, Flynn E, Ji RW and Folkman J Expression of angiostatin cDNA in a murine fibrosarcoma suppresses primary tumor growth and produces long-term dormancy of metastases, J. Clin. Invest 101: 1055-1063, 1998. [PubMed: 9486976]

86. Baker AH, George SJ, Zaltsman AB, Murphy G, and Newby AC Inhibition of invasion and induction of apoptotic cell death of cancer cell lines by overexpression of TIMP-3, Br. J. Cancer 79: 1347-55, 1999. [PubMed: 10188875]

87. Valente P, Fassina G, Melchiori A, Masiello L, Cilli M, Vacca A, Onisto M, Santi L, StetlerStevenson WG, and Albini A TIMP-2 over-expression reduces invasion and angiogenesis and protects B16F10 melanoma cells from apoptosis [published erratum appears in Int J Cancer 1999 Jan 29;80(3):485], Int. J. Cancer 75: 246-253, 1998. [PubMed: 9462715]

88. Machein MR, Risau W, and Plate KH Antiagiogenic gene therapy in a rat glioma model using a dominant-negative vascular endothelial growth factor receptor 2, Hum. Gene Ther 10: 1117-1128, 1999. [PubMed: 10340544]

89. Wang Y, and Becker D Antisense targeting of basic fibroblast growth factor and fibroblast growth factor receptor-1 in human melanomas blocks intratumoral angiogenesis and tumor growth, Nat. Med 3: 887-893, 1997. [PubMed: 9256280]

90. Sasaki M, Wizigmann-Voos S, Risau W, and Plate KH Retrovirus producer cells encoding antisense VEGF prolong survival of rats with intracranial GS9L gliomas, Int. J. Dev. Neurosci 17: 579-591, 1999. [PubMed: 10571419]

91. Luo D and Saltzman WM Synthetic DNA delivery systems [In Process Citation], Nat. Biotechnol 18: 33-37, 2000. [PubMed: 10625387]

92. Robbins PD and Ghivizzani SC Viral vectors for gene therapy, Pharmacol. Ther 80: 35-47, 1998. [PubMed: 9804053]

93. Romanczuk H, Galer CE, Zabner J, Barsomian G, Wadsworth SC, O'Riordan CR Modification of an adenoviral vector with biologically selected peptides: a novel strategy for gene delivery to cells of choice, Hum. Gene Ther 10: 2615-2626, 1999. [PubMed: 10566889]

94. Coll JL, Chollet P, Brambilla E, Desplanques D, Behr JP, and Favrot M In vivo delivery to tumors of DNA complexed with linear polyethylenimine, Hum. Gene Ther 10: 1659-1666, 1999.

[PubMed: 10428211] 
95. Perales JC, Ferkol T, Beegen H, Ratnoff OD, and Hanson RW Gene transfer in vivo: sustained expression and regulation of genes introduced into the liver by receptor-targeted uptake, Proc. Natl. Acad. Sci. USA 91: 4086-4090, 1994. [PubMed: 8171039]

96. Thurston G, McLean JW, Rizen B, Haskel A, Murphy TJ, Hanahan D, and McDonald DM Cationic liposomes target angiogenic endothelial cells in tumors and chronic inflammation in mice, J. Clin. Invest 101: 1410-1413, 1998.

97. Arap W, Pasqualini R, and Ruoslahti E Cancer treatment by targeted drug delivery to tumor vasculature in a mouse model [see comments], Science. 279: 377-380, 1998. [PubMed: 9430587]

98. Pasqualini R, Koivunen E, and Ruoslahti E Alpha v integrins as receptors for tumor targeting by circulating ligands [see comments], Nat. Biotechnol 15: 542-546, 1997. [PubMed: 9181576]

99. Li S and Huang L In vivo gene transfer via intravenous administration of cationic lipid- protamineDNA (LPD) complexes, Gene Ther. 4: 891-900, 1997. [PubMed: 9349425]

100. Li S, Rizzo MA, Bhattacharya S, and Huang L Characterization of cationic lipid-protamine-DNA (LPD) complexes for intravenous gene delivery, Gene Ther. 5: 930-937, 1998. [PubMed: 9813664]

101. Hong K, Zheng W, Baker A, and Papahadjopoulos D Stabilization of cationic liposome-plasmid DNA complexes by polyamines and poly(ethylene glycol)-phospholipid conjugates for efficient in vivo gene delivery, FEBS Lett. 400: 233-237, 1997. [PubMed: 9001404]

102. Ogris M, Brunner S, Schuller S, Kircheis R, and Wagner E PEGylated DNA/transferrin-PEI complexes: reduced interaction with blood components, extended circulation in blood and potential for systemic gene delivery, Gene Ther. 6: 595-605, 1999. [PubMed: 10476219]

103. Dow SW, Fradkin LG, Liggitt DH, Willson AP, Heath TD, and Potter TA Lipid-DNA complexes induce potent activation of innate immune responses and antitumor activity when administered intravenously, J. Immunol 163: 1552-1561, 1999. [PubMed: 10415059]

104. Kukowska-Latallo JF, Bielinska AU, Johnson J, Spindler R, Tomalia DA, Baker JR, Jr. Efficient transfer of genetic material into mammalian cells using Starburst polyamidoamine dendrimers, Proc. Natl. Acad. Sci. USA 93: 4897-4902, 1996. [PubMed: 8643500]

105. Ferrari S, Moro E, Pettenazzo A, Behr JP, Zacchello F and Scarpa M ExGen 500 is an efficient vector for gene delivery to lung epithelial cells in vitro and in vivo, Gene Ther. 4: 1100-1106, 1997. [PubMed: 9415317]

106. Behr JP, Demeneix B, Loeffler JP, and Perez-Mutul J Efficient gene transfer into mammalian primary endocrine cells with lipopolyamine-coated DNA, Proc. Natl. Acad. Sci. USA 86: 69826986, 1989. [PubMed: 2780554]

107. Ogris M, Steinlein P, Kursa M, Mechtler K, Kircheis R, and Wagner E The size of DNA/ transferrin-PEI complexes is an important factor for gene expression in cultured cells, Gene Ther. 5: 1425-1433, 1998. [PubMed: 9930349]

108. Ye X, Rivera VM, Zoltick P, Cerasoli F, Schnell MA Gao G-P, Hughes JV Gilman M, and Wilson JM Adeno-associated regulated delivery of therapeutic proteins after in vivo somatic cell gene transfer, Science. 283: 88-91, 1999. [PubMed: 9872748]

109. Chang LJ, Urlacher V, Iwakuma T, Cui Y, and Zucali J Efficacy and safety analyses of a recombinant human immunodeficiency virus type 1 derived vector system, Gene Ther. 6: 715728, 1999. [PubMed: 10505094]

110. Emerman M From curse to cure: HIV for gene therapy?, Nat. Biotechnol 14: 943, 1996. [PubMed: 9631028]

111. Kalpana GV Retroviral vectors for liver-directed gene therapy, Semin. Liver Dis 19: 27-37, 1999. [PubMed: 10349681]

112. Park F, Ohashi K, Chiu W, Naldini L, and Kay MA Efficient lentiviral transduction of liver requires cell cycling in vivo [In Process Citation], Nat. Genet 24: 49-52, 2000. [PubMed: 10615126]

113. Wolff JA, Malone RW, Williams P, Chong W, Acsadi G, Jani A, and Felgner PL Direct gene transfer into mouse muscle in vivo, Science. 247: 1465-1468, 1990. [PubMed: 1690918]

114. Mir LM, Bureau MF, Rangara R, Schwartz B, and Scherman D Long-term, high level in vivo gene expression after electric pulse- mediated gene transfer into skeletal muscle, C. R. Acad.. Sci.. III 321: 893-899, 1998. [PubMed: 9879468] 


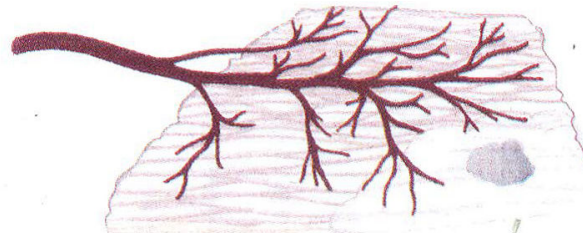

Tumor
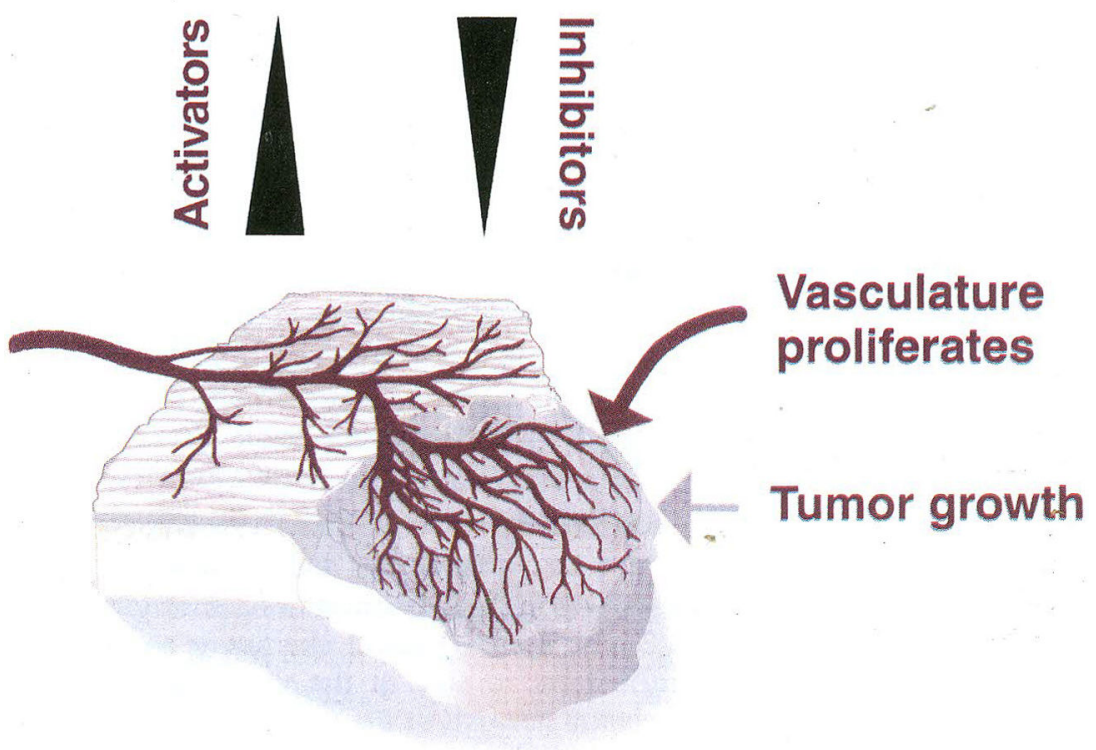

Figure 1. Promotion of tumor growth by angiogenesis.

In order for tumors to progress from in situ to large tumors, increases in the proangiogenic factors coupled with decreases in the antiangiogenic factors are required (see Table I for list of activators or inhibitors). The thickness of the arrow represents the respective gradients of activators/inhibitor molecules. 


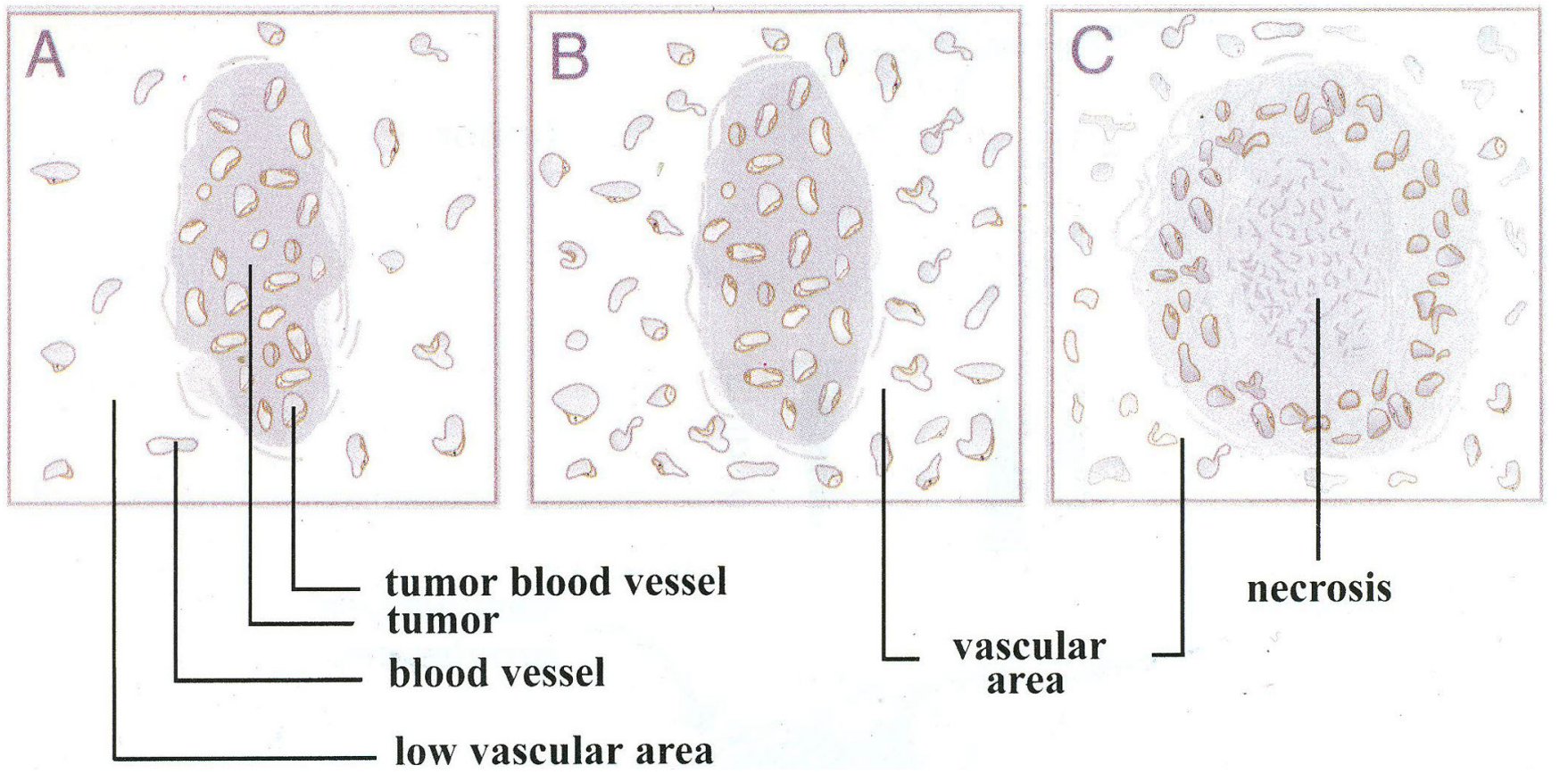

Figure 2. Models of VEGF Expression in Tumor Growth.

A) In tissues with low vascularity, marked increases in VEGF and angiogenesis occur when the tumor size reaches $2 \mathrm{~mm}$ in diameter. $\mathrm{B}$ ) and C) demonstrate a second model of VEGF expression in tumors that have metastasized to vascular tissues. In early stages of tumor growth (B), increases in VEGF and angiogenesis do not initially occur when the tumor is 2 $\mathrm{mm}$ in size. Instead, the tumor co-opts the vessels of the organ. At a later stage $(\mathrm{C})$ when the tumor reaches several centimeters in size in the vascular tissue, VEGF, angiopoietin 2, and angiogenesis at the periphery increase, accompanied by central necrosis of the tumor. 


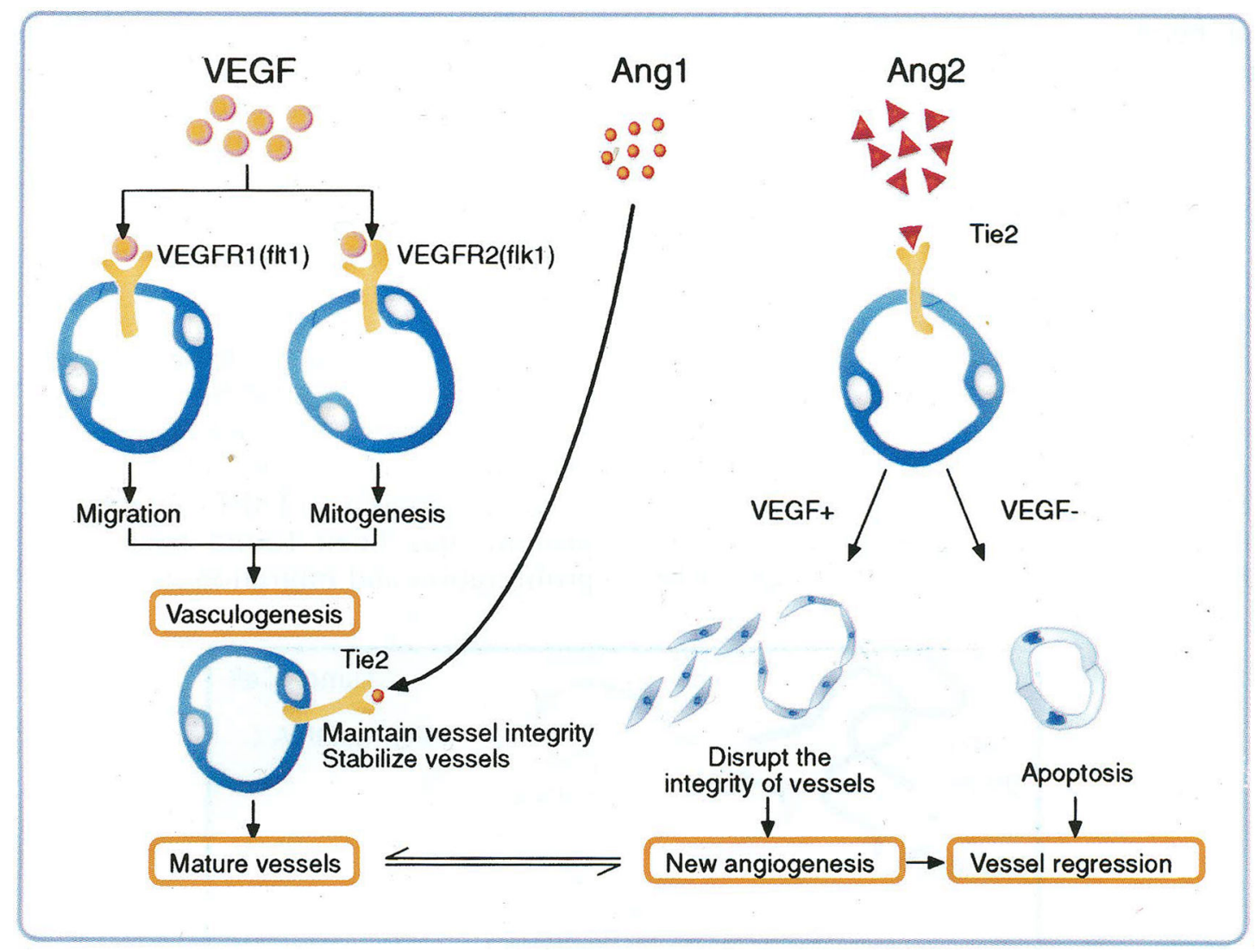

Figure 3. Functions of various angiogenic regulators:

Two VEGF receptors, VEGFR1 and VEGFR2, are localized to mitogenic endothelial cells. VEGF, by binding to VEGFR1, induces migration of endothelial cells, while activation of VEGFR2 is essential for mitogenesis. In addition to VEGF/VEGFR, angiopoietin 1 (Ang1) and angiopoietin 2 (Ang2) appear to have important physiologic roles in vessel formation and stabilization. Although angiopoietins 1 and 2 have similar binding affinity to the endothelium-specific receptor, Tie2, the consequences of their binding are different. By activating Tie 2, Ang1 stabilizes vessels. In contrast, Ang2 does not activate Tie2. Rather, up-regulation of Ang2 stimulates angiogenesis in the presence of VEGF, but induces apoptosis in the absence of VEGF. 


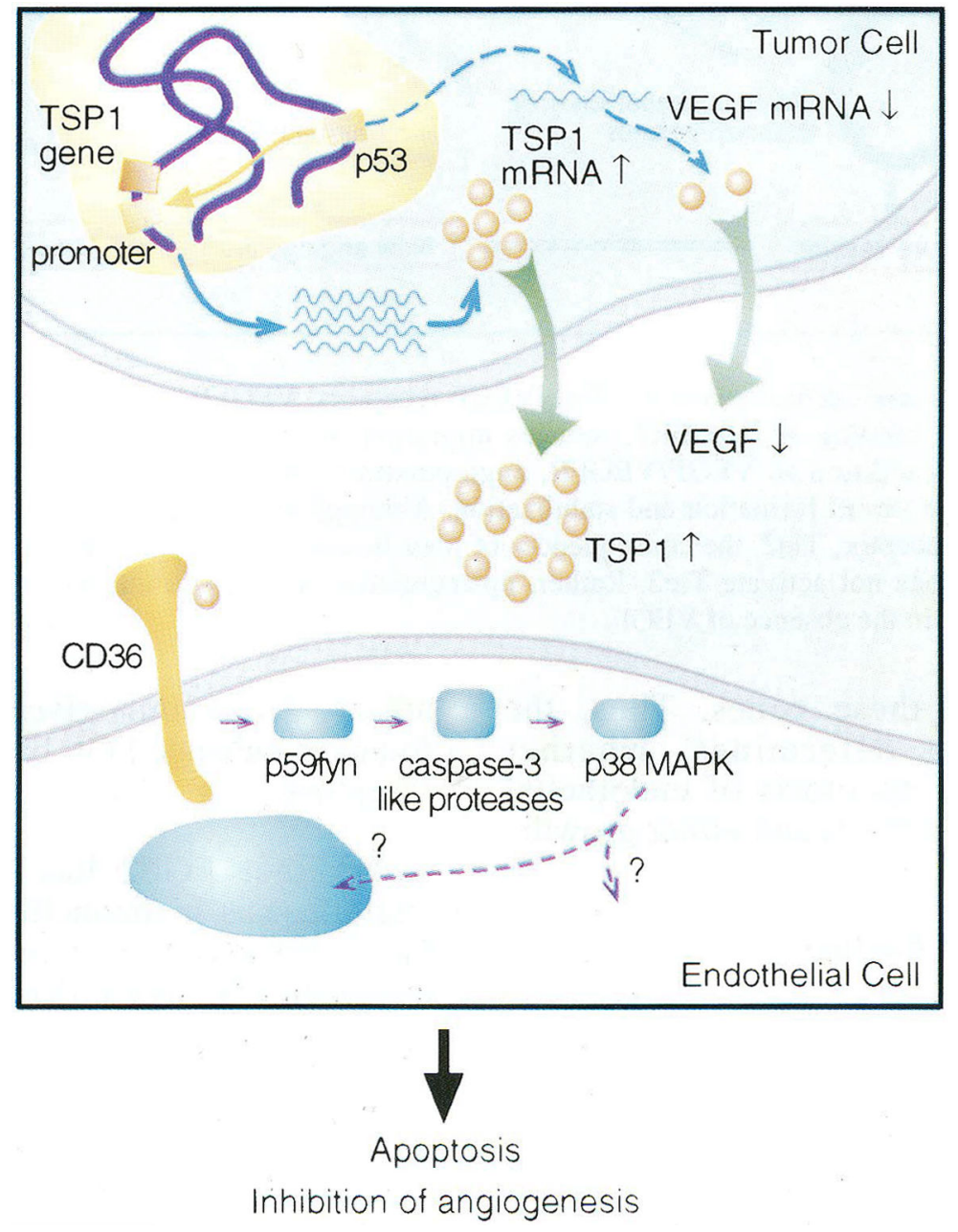

Figure 4. Proposed mechanisms for inhibition of angiogenesis by p53.

Two important mechanisms by which P53 may inhibit angiogenesis in neoplasms are induction of the antiangiogenic protein, TSP1, and decreased expression of the proangiogenic protein, VEGF. After wild-type p53 transcriptionally up-regulates TSP1 in the tumor cell, the secreted TSP1 binds to and activates the endothelial surface receptor, CD36. Several proteins, including p59fyn, caspase-3 like proteases, and p38 mitogen-activated protein kinase (p38MAPK), are then sequentially activated leading to apoptosis of the endothelial cell. Many of the mediators of the apoptotic signal transduction pathway downstream of p38MAPK have not yet been identified. A second mechanism by which p53 may inhibit angiogenesis is by decreasing the pro-angiogenic factor, VEGF. It is not clear whether down-regulation of the VEGF by p53 occurs at the transcriptional or at the posttranslational stage. Pharmacological delivery of the p53 gene may result in the inhibition of angiogenesis by additional mechanisms (see section IIA). 


\section{Table I}

Endogenous Regulators of Tumor Angiogenesis

\begin{tabular}{|c|c|}
\hline Activators & Inhibitors \\
\hline Vascular Endothelial Growth Factor (VEGF) & p53 \\
\hline Fibroblast Growth Factor 1 (FGF1) & Thrombospondin- 1 \\
\hline Fibroblast Growth Factor 2 (FGF2) & Thrombospondin-2 \\
\hline Platelet Derived Growth Factor (PDGF) & Tissue Inhibitors of Metalloproteinases (TIMPS) \\
\hline Angiopoietin $2+$ VEGF & Angiostatin \\
\hline Angiopoietin $1^{2}$ & Endostatin \\
\hline Transforming Growth Factor- $\beta^{1}$ (TGF- $\beta$ ) & Antiangiogenic Antithrombin III \\
\hline Tumor Necrosis Factor-a ${ }^{1}$ (TNF-a) & Angiostatic C-x-C chemokines (PF4, IP10, MIG) \\
\hline Interleukin-8 (IL-8) & Pigment Endothelial Derived Factor (PEDF) \\
\hline Platelet Derived Endothelial Cell Growth & Interleukin-12 (IL-12) \\
\hline Factor (PD-ECGF) & Interferon (INF)- $\alpha, \beta, \gamma$ \\
\hline \multicolumn{2}{|l|}{ Hepatocyte Growth Factor (HGF) } \\
\hline 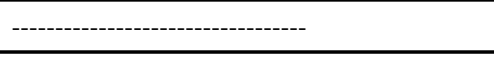 & \\
\hline -Dose-dependent & \\
\hline
\end{tabular}


Table II

Gene Therapy of Antiangiogenic Inhibitors

\begin{tabular}{|c|c|c|c|}
\hline Angiogenic Inhibitor & Tested in vivo & Mechanism & Method of Delivery \\
\hline VEGF antisense & Yes & $\downarrow$ VEGF & ex vivo; Co-injection \\
\hline Adenosine Type II receptor antisense & No & $\downarrow$ Type II Receptor and VEGF & NA \\
\hline VEGFR2-DN & Yes & Inhibits VEGFR & Co-injection \\
\hline sVEGFR1 & Yes & $\downarrow$ VEGF and inhibits.VEGFR & ex vivo; IV \\
\hline Tie2 & Yes & $\downarrow$ Angiopoietin 2 & IV \\
\hline FGF2 Antisense & Yes & $\downarrow \mathrm{FGF} 2$ & ex vivo \\
\hline $\mathrm{p} 53^{1}$ & Yes & Inhibits cell cycle ${ }^{2}, \uparrow$ thrombospondin $1 ; \downarrow$ VEGF & ex vivo; IT; IV \\
\hline Thrombospondin 1 & Yes $^{3}$ & Activates caspases & ex vivo; IV \\
\hline Thrombospondin 2 & Yes & $?$ & ex vivo \\
\hline Angiostatin & Yes & ? Inhibits ATP Synthase & ex vivo; IT; IV \\
\hline Endostatin & Yes & $?$ & IT;IV;IM \\
\hline Antithrombin III & No & $?$ & NA \\
\hline $\mathrm{IL}-12^{1}$ & Yes & INF- $\gamma$ & IT;IV;IM. \\
\hline PEDF & No & $?$ & NA \\
\hline
\end{tabular}

Symbols: VEGFR-DN, truncated VEGF receptor that dimerizes and inhibits the wild-type receptor; IT, intratumoral injection; IM, intramuscular injection; IV, intravenous injection; NA, not applicable

1 Ongoing Clinical Trials

2 Inhibits cell cycle of endothelial cells

${ }^{3}$ Genes encoding antiangiogenic peptides of thrombospondin 1 have been delivered IV. 